\title{
GHOST DANCING WITH COLONIALISM: DECOLONIZATION AND INDIGENOUS RIGHTS AT THE SUPREME COURT OF CANADA, GRACE Li XIU WOO(VANCOUVER: UBC PRESS, 2011)
}

I write this review at the request of the Alberta Law Review. I assume they asked me for a couple of reasons. First, I sat as a judge for over thirty years, presiding over most of the cases arising on the Stoney Indian Reserve at Morley, Alberta. Second, I have written a book, based on that experience, entitled Bad Medicine: A Judge's Struggle for Justice in a First Nations Community. ${ }^{1}$

Notwithstanding my credentials, I found Ghost Dancing with Colonialism: Decolonization and Indigenous Rights at the Supreme Court of Canada ${ }^{2}$ to be a very difficult read. I describe the style in which it is written as highly academic. It is so academic that I often had to re-read the same passage several times in order to understand what the author was saying. I think this is unfortunate because the book contains an important and powerful message, but it is predictable that it will have a limited readership because it is simply too academic for a mainstream audience. The basic message of this book is that the way we thought in the past made the prior manner of treatment of Indigenous people seem okay. Today, we acknowledge this manner of treatment is not appropriate, but further changes in our thinking are required in order for practice to correspond to the talk.

Colonial Canada dispossessed Aboriginal people and deprived them of their right to selfdetermination. The passage of the Constitution Act, $1982^{3}$ moved Canada away from the last vestiges of its colonial connection to Britain. Section 35 of the Constitution Act, 1982 recognized and affirmed the existing Aboriginal and treaty rights of the Aboriginal peoples of Canada. This should have ended the colonial era, but has Canada really become "postcolonial”? Woo's colonial/post-colonial analysis of 65 cases from the Supreme Court of Canada relating to Aboriginal people demonstrates that we are making an effort, but that the requisite change in thinking is happening all too slowly.

A personal benefit I gained from reading this book was an understanding of the word "paradigm.” This word has always given me difficulty, perhaps because I wanted a simple definition of a word that names a very complex concept. Woo devotes a whole chapter to the explanation of paradigm theory, and she agrees that the use of the word paradigm has acquired a "trendy panache." 4 I find the use of the word is typical of the style in which academics speak. That style, in my view, prevents many non-academics from understanding what is being said. In my career as a judge, I sat in criminal courts and became painfully aware of the fact that the majority of the people appearing before me had very limited education, and often did not understand what was being said. I made an effort to speak in a manner that they could understand. I believe many of them would not understand the prose in this book. 
I now understand paradigm to be like a box full of ideas. There are accepted ideas that go in the box, and there are rejected ideas that do not. The understanding of any issue is then dependent on what is in the box. When issues arise that cannot be understood by what is in the box, we refer to them as anomalies. When the anomalies persist, we are required to change the paradigm. Paradigm change is a slow and difficult process. The pre-1930 Canadian paradigm did not include the idea that a woman was a person. A man in 1929 could say that all persons in Canada have the right to vote and he would be making a correct statement, even though women, Indians, Chinese, and others did not have that right. The idea that these people were persons was not in his box of ideas. In 1930, in Edwards v. Canada, ${ }^{5}$ the Judicial Committee of the Privy Council, ruled that women are in fact persons. So, the post-1930 Canadian paradigm includes that idea. We might expect this would have produced immediate equality for women, but notwithstanding significant gains, their struggle goes on today, almost 100 years after the Person's case.

One of the writings that had huge impact on my thoughts in relation to Aboriginal matters was the Cawsey Report. ${ }^{6}$ Its treatise on "world view" opened my mind to the fact that different people see the world differently. Had Cawsey employed the "panache" of current academia, he might have described this in terms of paradigms. What Grace Woo wants us to understand is not the difference in paradigms from one race to another, but from one generation to another. Some of what was considered acceptable to our ancestors in their social paradigm, we now consider criminal because our social paradigm has changed.

Woo sets out a number of historical facts that are crucial to our understanding of the right of self-determination of Aboriginal people. Section 35 of the Constitution Act, 1982 and the United Nations Declaration on the Rights of Indigenous Peoples, ${ }^{7}$ which Canada has now signed, have theoretically confirmed these rights, but the struggle to put them into practice continues. The first of these rights is the right of sovereignty, symbolized by the Haudenosaunee by the Two Row Wampum. ${ }^{8}$ This symbol represents the treaty between themselves and the English. The two purple rows on the background of white symbolize the separation of the nations. The Iroquois never agreed to become subjects of the English Crown - they were allies. Further, they have never agreed to be subject to the government of Canada. As the settler population grew and became dominant, the Canadian government just assumed the power to govern them without ever obtaining their consent. The governing of a people without their consent is a primary feature of colonialism.

Woo does not speak of Treaty 7, which governs the First Nations in Southern Alberta, the jurisdiction where I sat as a judge. It is my understanding that when Chief Crowfoot of the Blackfoot First Nation agreed to enter this treaty he said, approximately, "We will share the land with our white brothers." He accepted the protection of the Crown, but he did not agree to be governed by it. The Blackfoot never agreed to be governed by England, and when Canada became independent from England, it could only acquire the relationship with the Aboriginal people that England had possessed. 
I particularly endorse Woo’s statement at page 20:

Whatever its origins, Canada's current constitutional treatment of Indigenous peoples contradicts the practice of negotiating on a nation-to-nation basis that had been so staunchly defended by Sir William Johnson, the first superintendent of Indian Affairs. Assaults on Indigenous rights certainly intensified following Confederation. Officials in the Department of Indian Affairs applied unilateral interpretations of both treaties and Canadian law. They compared Indigenous people to children who were wards of the state, and, because there was no Indigenous representation in Parliament, their advice was followed by whoever the presiding minister happened to be. As a result, the Indian Act was revised frequently in ways that enhanced the bureaucratic power to veto Indigenous political and economic decisions. Many Indigenous people complained, but the Department had a vested interest in stifling anything that could be taken as criticism. This was the dynamic through which the age of "Displacement and Assimilation” identified by the Royal Commission on Aboriginal Peoples functioned. ${ }^{9}$

I was somewhat surprised at first, but then came to agree with her assertion that even the granting of the vote to "Indians" in 1960 was, in fact, an act of colonialism. It simply told the Aboriginal peoples that they were citizens of Canada without asking them if they wanted to be citizens of Canada. The fact that they live in the geographic area that is covered by what is known as Canada does not deprive them of the right to determine for themselves whether or not they want to be citizens of Canada.

Reading this book has given me cause to re-examine my own thinking on Aboriginal people. In my work as a judge I became painfully aware of the poverty and dysfunction in the Aboriginal community. I came to the conclusion that the offenders themselves were victims of this dysfunction, and that sending them to prison for their dysfunctional behavior, when nothing was being done to fix their dysfunctional community, was just further injustice. I tried to ameliorate the law by imposing treatment-oriented sentences that did not comply with precedents that mandated imprisonment. On reflection, I see myself operating in the paradigm that thinks of the Aboriginal as a dependent ward, and I see myself as just being paternalistic. I still agree with my result, but having read this book, my reasoning would be different.

One aspect of sovereignty is the right to have traditional laws recognized. Woo explains that the Coronation Oath, that was taken by English kings from early times, was an oath by which they accepted the loyalty of the people and undertook to protect them and govern them according to the "law of the land." 10 The expression "law of the land" included the laws of the people to be governed. The government of Canada, having acquired authority through English common law, is bound to govern according to the laws of the land. Those laws include the laws by which the Aboriginal peoples governed themselves. So, if I had it to do over, I would continue my efforts to ameliorate the criminal law in relation to Aboriginal offenders, but rather than do this on a basis of attempting to right wrongs, past and present, I would advance the following reasoning: 
1. The Aboriginal offender is a member of a separate nation and is entitled to have his traditional laws recognized.

2. My jurisdiction over this offender is an anomaly. He should be answering to his own judicial system. The process of attrition by which Canada has assumed jurisdiction over him is contrary to the legality of the historic relationship between Euro-centric Canada and Aboriginal Canada. I only assume jurisdiction by reason of necessity. I find that in doing so I must give recognition to his traditional laws.

3. His traditional laws emphasized healing and teaching as the accepted methods of behavior modification and only resorted to banishment as a last resort. Therefore, in order to give recognition to his traditional laws, I will emphasize healing and teaching in passing sentence and only resort to imprisonment (the equivalent of banishment) as a last resort.

My judgments in the late 1990s were criticized for demonstrating a lack of objectivity in relation to the Aboriginal offender. Woo's reasoning in this regard suggests that there is, in fact, a lack of objectivity within the legal system as a whole. In making this suggestion, I feel that her reasoning supports the approach that I took towards Aboriginal offenders. In coming to her conclusion, Woo specifically points out the inherent lack of objectivity in the Supreme Court of Canada. The Court was created without input from the Aboriginal people. There are no Aboriginal members on the Court. Laws that the Court interprets and applies were passed without Aboriginal input, and in many cases, at a time when Aboriginal peoples were not even considered persons. In her colonial/post-colonial analysis of Supreme Court cases, Woo uses the following ten criteria:

1. The Judge - the colonial judge is imposed on the parties; the post-colonial judge acts with the consent of the parties.

2. The Parties - the colonial Court assumes the identity of the parties (Aboriginals are Canadians subject to Canadian law); the post-colonial Court respects the self identification the parties (for example, the sovereign Haudenosenee).

3. The Venue - the Court is inherently colonial because it is a creation of the colonial culture. It moves toward the post-colonial by accommodation of Aboriginal perspectives and language.

4. The Issues - issues are colonial when framed by colonial culture, such as laying of criminal charges, and are post-colonial when Aboriginals frame the issues, as by initiating litigation.

5. The Procedure - colonial procedure would be in camera and biased; post-colonial procedure is public, allows interveners, and gives equal footing to parties. This is part of Anglo-Canadian tradition and all cases scored well on the post-colonial side, with some reservations. 
6. The Evidence - colonial decisions are based on assumptions, while post-colonial decisions are based on evidence. Again, this is Anglo-Canadian tradition, but there were reservations about some assumptions made by the Court.

7. The Concept of Law - is colonial when imposed and post-colonial when consensual. All cases are colonial because they apply laws that were passed without input of the Aboriginal people. This is modified somewhat by efforts to acknowledge post-colonial legality, however this is an ideal yet to be achieved.

8. The Reasoning - is colonial when declaratory and post-colonial when reasoned. Canadian tradition scored high on this count, with exceptions largely the product of entrenched generalizations that failed to take account of Indigenous reality.

9. The Values - colonial law relies on hierarchical authority and the use of force; postcolonial law is grounded in the principles of mutual respect and human equality. While the Court attempted to give effect to egalitarian principals, it frequently fell back on the authoritarian.

10. The Perspective - colonial perspective presumes only one correct way to look at things; post-colonial perspective recognizes multiple systems of thought and ensures cross cultural respect. Again, the Court would acknowledge the Aboriginal perspective, but would frequently fall back on its own tradition.

Woo admits that her criteria are subjective and that her values would be subject to debate, but her method achieves the goal of describing the paradigm change that is taking place and the further change that is necessary. The cases she uses in her analysis are unfortunately not summarized in the text of the book. Some can be found in the appendices and for the rest the reader is referred to a web site.

In conclusion, I repeat my introductory comment that there is an important and valuable message in this book. In the course of my judicial career I was deeply engaged in Aboriginal justice and made a significant effort to inform myself of the issues facing Canada's Aboriginal people. My struggle through the pages and appendices of Ghost Dancing with Colonialism has given me a deeper understanding of the issues, a little more information, and a few new insights. It has been well worth the effort I put into it.

The Honourable John D. Reilly Provincial Court of Alberta (retired) 